\title{
The Impact of Computer-based Test and Students' Ability in Computer Self - Efficacy on Mathematics Learning Outcomes
}

\author{
Nurhikmah $\mathrm{H}^{1 *}$, Farida Febriati ${ }^{2}$, Ervianti ${ }^{3}$ (D) \\ 1,2,3 Program Studi Teknologi Pendidikan, Universitas Negeri Makassar, Makasar, Indonesia
}

\section{A R T I C L E I N F O}

Article history:

Received June 01, 202

Revised June 11, 2021

Accepted October 12, 2021

Available online November 25, 2021

Kata Kunci:

CBT, Self Efficacy, Hasil Belajar

Keywords:

CBT, CSE, Learning Outcomes

DOI:

https://dx.doi.org/10.23887/jet.v5i4.3 4942

\begin{abstract}
A B S T R A K
Era digitalisasi saat ini sangat berpengaruh terhadap dunia pendidikan, penggunaan teknologi dan informasai dalam dunia pendidikan tidak hanya untuk pembelajaran tapi sebagai alat evaluasi. Perkembangan ini menimbulkan permasalahan yang membutuhkan penyelesaian pemikiran tingkat tinggi oleh karena itu peserta didik perlu mempersiapkan kemampuan dalam berfikir dan mampu mengembangkan keterampilan. Penelitian ini bertujuan untuk ntuk menganalisis Self efficacy Kemampuan Komputer terhadap hasil belajar siswa dan interaksi pada mata pelajaran matematika. Metode penelitian ini pendekatan kuantitatif dengan jenis penelitian eksperiman. Model penelitian eksperimen yang digunakan mengacu pada Quasi Eksperimen Design. Sampel penelitian secara keseluruhan 64 siswa. CBT digunakan dalam evaluasi mata pelajaran matematika dan digunakan angket untuk mengetahui tingkat self efficacy kemampuan komputer terhadap hasil belajar siswa pada mata pelajaran Matematika. Analisis data penelitian dilakukan dengan menggunakan ANOVA dua arah (two-way ANOVA) dengan menggunakan program software SPSS versi 25.0. Hasil penelitian menunjukkan bahwa terdapat pengaruh CBT mata pelajaran matematika terhadap hasil belajar siswa dengan rerata nilai 85 dan rerata nilai 80 dan terdapat pengaruh self efficacy kemampuan komputer siswa dengan kriteria nilai 3.03 sangat berpengaruh dan kriteria nilai 2.78 berpengaruh. Interaksi Antara CBT dengan self efficacy kemampuan komputer memiliki korelasi sangat sempurna dengan hubungan positif. Hal ini berarti dapat di nyatakan bahwa terdapat pengaruh CBT dan self efficacy kemampuan komputer dan memiliki interaksi Antara computer-based test dan self efficacy terhadap hasil belajar siswa.
\end{abstract}

\section{A B S T R A C T}

The current era of digitalization has big impact on education, the use of technology and information is not only for learning but as an evaluation tool. This development raises problems that require the completion of high-level thinking, therefore students need to prepare the ability to think and be able to develop skills. This study aims to measure the self-efficacy of computer skills on student learning outcomes and interactions in mathematics subjects. This research method used quantitative approach in Quasi Experiment Design. Total sample were 64 students. CBT was used in evaluating mathematics subjects and using a questionnaire to determine the level of self-efficacy of computer abilities towards students learning outcomes. Analysis of research data was carried out using ANOVA, to test the hypothesis using two-way ANOVA (two-way ANOVA) using the SPSS version 25.0 for windows software program. The results showed that there was CBT of mathematics subjects towards student learning outcomes with a mean score of 85 in and a mean score of 80 with a criterion of 3.03, having impact and the criteria value 2.78. The interaction between computer-based tests with self-efficacy computer capabilities had the most correlation with a positive relationship. It can be stated that there is an impact of computer-based tests and self-efficacy of computer ability and has an interaction between CBT and self-efficacy on learning outcomes.

This is an open access article under the CC BY-SA license. Copyright @ 2021 by Author. Published by Universitas Pendidikan Ganesha.

\section{INTRODUCTION}

The advent of the technology has caused a lot of change in all professions (Barnes et al., 2019; Dong et al., 2020). Changes and developments in educational evaluation occur because the measurement of educational standards has not been achieved and considered that not efficient enough, especially in the current era of the Covid 19 pandemic (Mpungose, 2021; Yuzulia, 2021). It is regarding the procurement of computer-based tests. With the development of computer-based information technology can make learning easier to process, especially in educational assessments or evaluating student learning outcomes (Hwang et al., 2011; Zijlstra et al., 2021), 
With technology and information is increasing rapidly, including in education. By means of the event of Information and Technology, some of us do innovation through IT that may be accustomed facilitate others in doing daily activities, starting from causation messages, assignments and communicate online, explore for and obtain several things by online, order tickets and modes of transportation online and plenty of others (Azizah et al., 2020; Hussein et al., 2020; Inceday1, 2018). Through utilization of information technology (computers) as one of the media used for exams or tests is called a computer-based test (CBT). Computer-based test is a test that is conducted by using a computer as the main medium in conducting exam activities (Balogun \& Olanrewaju, 2016; Liao et al., 2018). Changing the implementation of conventional exams to computer-based exams is not easy, because it requires teachers to think creatively to update and CBT reduces examination malpractice, it is more secure, and it is one of the best global practices (Kartika et al., 2019; Valle et al., 2019).

Furthermore, it is expected to be able to answer the shortcomings of conventional exams, computerbased tests can be used as a medium for both national exams and daily and semester exams (Chua \& Don, 2013; Daniels \& Gierl, 2017). Tests in online provides advantages, namely in terms of teachers being able to prepare higher quality material as test material, the test administration process will be standardized, and can control student motivation. The cause of anxiety when facing an exam is because the exam is perceived as difficult, opposing and threatening, students see themselves as someone who is unable or unable to take the exam (Daniels \& Gierl, 2017; Valle et al., 2019). This is viewed from the cognitive aspect, anxiety can occur because of a negative perception of one's abilities. This technology has some roles such as using in exam (Chua \& Don, 2013). This exam has any kind require mental and physical preparation, as well as maturity in preparation. Semester exams as well as daily exams can also be considered a mental burden for those who are not ready to overcome and deal with various possibilities, succeed or fail. This makes students need to develop resilience.

The CBT is used through Mathematics subject, it is one of the most basic subjects that have different levels of difficulty. Anxiety about mathematics and low self-efficacy can be obstacles in the mathematics teaching process (Abosalem, 2016; Tse et al., 2019). Students who have high anxiety in mathematics tend to have low self-efficacy (Rosidah et al., 2018; Sagala \& Andriani, 2019). Therefore, students are expected to have high self-efficacy. And the use of computers as a medium used in the evaluation can affect learning outcomes in mathematics. One of the internal factors that can affect student learning outcomes is self-efficacy. Self-efficacy influences thinking processes, motivation levels, and feeling states which all play a role in the type of performance performed. Students' self-efficacy and deducing anxiety have been recognized as important factors to be considered in educational settings (Hung et al., 2014; Yada et al., 2021). It is a person's belief in being able to master a certain situation and the ability to overcome an obstacle. Self-efficacy has a major influence on behavior. If an individual has high self-efficacy, he will be able to face all the tasks and problems in his life (Pellas, 2014; Zetriuslita et al., 2020). Computer self-efficacy is conceptualized as an undergraduate student's judgment and belief in his/her capability to impactively execute, perform and succeed in CBT and other computer-related activities (Hatlevik et al., 2018b; Taruh et al., 2019).

In findings research found that students with higher computer self-efficacy tended to spend more time using online learning technology and were therefore more engaged in the learning processes (Bressington et al., 2018; Sun \& Rueda, 2012). There are some previous studies had conducted by some researchers stated that the student self-efficacy had a major influence on students' mathematical thinking in solving mathematical problems. This is because mathematics holds a prominent place in the academic curriculum, and academic success in this subject is very important in today's fast-paced scientific and technological age, so self-efficacy is very important in solving mathematical problems (Achim and Kassim 2015). This study conveyed that ICT self-efficacy is positively related to computer and information literacy when controlled for other student characteristics and background contextual variables and ICT self-efficacy one hand and computer and information literacy on the other. It is therefore necessary to continue elaborating on the differences between what students belief they can do when using ICT and their actual performance with ICT (Hatlevik et al., 2018a). Also this study was supported that computer self-efficacy and subjective well-being are significant predictors of belief in research self-efficacy (Odaci, 2013). From some results of previous studies showed that the effect of computer-based tests on student learning outcomes. It indicated that thi research results and previous studies provided strong support both theoretically and empirically.

The use of computer-based tests in the evaluation of mathematics subjects requires good readiness to avoid anxiety. Computer skills self-efficacy as a person's perception of the ability to manage tasks or perform computer-related behavior (Dashtestani, 2013; Liao et al., 2018). Good Computer Self Efficacy skills will help students in solving mathematical problems (Gazali, 2017; Safi'i \& Bharata, 2021). It is necessary to know the level of self-efficacy of students' computer abilities in dealing with computer-based exams or computer-based tests and to find out the results of learning mathematics using computer-based tests whether there is a relationship with the level of self-efficacy of computer skills. The importance of mathematics cannot be separated from the benefits of mathematics in life. Mathematics is a logical way of thinking (Sagala \& Andriani, 2019; Zetriuslita et al., 2020). Mathematics can improve the ability to think logically, analytically, 
systematically, critically, and creatively, as well as the ability to work together. Students' perceptions of mathematics in general feel difficult, arid, and do not appear to be related to everyday life. Mathematics anxiety and low self-efficacy can become obstacles in the mathematics teaching process. Students who have high anxiety in mathematics tend to have low self-efficacy (Fonda \& Sumargiyani, 2018; Rachmawati, 2018). Mathematics is one of the subjects included in the National Examination which consists of four selected subjects, namely, mathematics, Indonesian, English and Science. Each subject has a different level of difficulty. Many demands are in the form of assignments that must be completed by their responsibility as students. Therefore, this study has some urgency such as to analyze the Impact of CBT on student learning outcomes in mathematics, to examine the Impact of Self-efficacy of Computer Capabilities on the learning outcomes, to clarify the interaction of CBT with Self-efficacy towards student learning outcomes

\section{METHOD}

This research used a quantitative approach with the type of experimental research to see the causal relationship of a treatment. This research is an experimental study that aims to find the effect of computer-based tests and self-efficacy of computer skills on student learning outcomes at SMP in Makassar. The research design used was a quasi-experimental design with a nonequivalent control group design model (R. Burke Johnson, 2014). None equivalent control group design model means that before being given treatment, both the experimental group and the control group were given a post test to determine the condition of the group before treatment. Furthermore, after being given treatment, the experimental group and the control group were given a posttest to determine whether the treatment given had an effect. The experimental group was given treatment using a computer-based test by looking at the self-efficacy of computer abilities and the control group was given without a computer-based test/paper test by looking at the self-efficacy of computer abilities. This experimental study took the subject of research in class VIII SMP in Makassar City which consisted of two schools namely SMP Negeri 6 Makassar and SMP Negeri 19 Makassar which amounted to 64 students from 2 namely the experimental group and the control group. Data collection techniques used are tests, questionnaires or questionnaires, and documentation. While the data analysis technique used is descriptive qualitative analysis and descriptive statistical analysis. The subject of research was two junior high schools with a total sample of 64 consisting of 32 students of class VIII at SMP Negeri 6 Makassar and 32 students of class VIII at SMP Negeri 19 Makassar. Class VIII was chosen as the research subject in order to see the readiness of students in working on computer-based questions. Data collection techniques used in research on CBT and self-efficacy of computer skills are, tests, questionnaires, observation and documentation. Data analysis used descriptive qualitative analysis and descriptive statistical analysis. The analysis was conducted to determine student responses to computer-based tests and self-efficacy on computer skills used in learning mathematics. The results of the study were analyzed to determine the presentation and frequency of student data.

The methods used to collect data are tests, questionnaires and documents. The instruments used to measure mathematics learning outcomes and instruments to measure self-efficacy of computer skills. Instruments to measure student learning outcomes used were multiple choice and essay with scoring rubrics ranging from 0 to 5 . The validity test of the self-efficacy questionnaire was carried out using the productmoment correlation technique from Pearson with calculations using the SPSS version 25 for windows program. The type of study used a quantitative approach through Quasi Experimental Design. The design used in this study was a quasi-experimental design and used the nonequivalent control group design model. Before being given treatment, both the experimental group and the control group were given a test, namely the pretest, with the intention of knowing the condition of the group before treatment. Then after being given treatment, the experimental group and the control group were given a posttest test, to determine the state of the group after treatment. The analysis was conducted to analyze student responses to computer-based tests and self-efficacy of computer ability used in learning mathematics. The results of the study were analyzed to determine the presentation and frequency of student data. The percentage of student responses was calculated. The type of ANOVA used was Two-Way Anova, because it only paid attention to two variables, namely the influenced Computer-based tests (CBT) and self-efficacy of computer abilities in improving student learning outcomes. Data analysis was processed using SPSS 25 for Windows.Analysis of research data was carried out using ANOVA, to test the hypothesis using two-way ANOVA (two-way ANOVA) using the SPSS version 25.0 for windows software program with a significance level of $5 \%$ or 0.05 


\section{RESULT AND DISCUSSION}

\section{Result}

Students in the experimental group and the control group obtained a significant difference in the average score of the average learning achievement. This means that through computer-based tests, the experimental group showed high learning outcomes in mathematics, and self-efficacy of computer skills greatly influenced learning outcomes. Meanwhile, in the control group, not undergoing computer-based test treatment, the results of learning mathematics were moderate, with self-efficacy having an effect on computer skills. The effect of the interaction between computer-based tests and self-efficacy of computer abilities on student learning outcomes in mathematics was carried out by correlation test with the results of correlation analysis obtained a significant value of 0.0000 .005 , which means that there is a relationship between variables. And seen from the Pearson correlation value, it is obtained at 0.815 which means that It had perfect correlation. Therefore, there is a positive relationship, namely the higher the self-efficacy of computer skills, the higher the learning outcomes using computer-based test (CBT). The type of research used experimental research in quasi-experimental design model. This study provided group therapy to analyze the effect of computer-based testing (CBT) and computerbased self-efficacy on student learning outcomes at SMP Negeri Makassar. Based on the experimental results of computer-based tests and observations of the self-efficacy of computer skills, the researcher got several results. The preliminary analysis was carried out by researchers to analyze the problems faced in learning mathematics. According to field observations, it should be noted that the level of student readiness in solving problems, especially student subjects, does need to be considered. Under the current pandemic phenomenon, all learning tools, both material access and evaluation, are carried out through online learning. Therefore, it is very sustainable in measuring the level of student readiness or better self-efficacy of computer skills

Based on observations from the results of computer-based testing experiments and self-efficacy of computer ability, several findings were obtained by researchers. The initial analysis was carried out by researchers to identify the problems faced in learning mathematics. With the current phenomenon with the Pandemic, all learning tools, both obtaining material and by conducting evaluations, are carried out by online learning. Therefore, it was very sustainable in measuring the level of student readiness or better known as selfefficacy in computer ability. The research was conducted at SMP Negeri 6 Makassar which is one of the schools in the city of Makassar. Researchers found several results in experiments conducted on mathematics class VIII subjects. Researchers used a sample of 32 students who were determined by class selection. In one class the researchers divided into two groups, namely the experimental group of 16 students and the control group of 16 students. In the experimental group, it was carried out by applying a computer-based test (CBT) to see if there was an impact of math scores on student learning outcomes. Furthermore, the experimental group was given a self-efficacy questionnaire on the ability of computers to measure students' readiness in facing computer-based exams. Research conducted at SMP Negeri 19 Makassar in mathematics class VIII researchers conducted research with a sample of 32 people who were determined by class selection. In one class the researchers divided into two groups, namely the experimental group of 16 students and the control group of 16 students. In the experimental group, it was carried out by applying a computer-based test (CBT) to see if there was an impact of math scores on student learning outcomes. Furthermore, the experimental group was given a self-efficacy questionnaire on the ability of computers to measure students' readiness in facing computer-based exams. And it can be found the influence of computer-based test (CBT) and self-efficacy of computer skills. Student learning outcomes using a computer-based test (CBT) showed results above the average standard KKM, namely 85.96, this shows that learning is successful, and there is an impact of student learning outcomes on mathematics using a computer-based test (CBT). While Student learning outcomes in mathematics class VIII can be said to be influential after using a computer-based test (CBT) above KKM 75 with the acquisition of an average score of student learning outcomes that is 80 .

Hypothesis testing uses the two-way ANOVA. Used to find out the truth of the hypothesis proposed. Then the data on the value of learning outcomes can be compiled a table serving the calculation of two-way ANOVA. To make it easier to analyze the data through the two-way ANOVA statistical test, SPSS 25.0 for windows was used in analyzing the hypothesis. From the results of the hypothesis test output with two-way ANOVA, it can be seen in the Tests of Between-subjects Impacts, which shows the computer-based test (CBT) group with a significance value of 0.351 , then 0.3510 .05 , H0 was rejected and $\mathrm{H} 1$ was accepted and a significant value of self-efficacy ability computer is 0.996 , then $0.996 \geq 0.05$. So it can be concluded that there was an impact of computer-based test (CBT) and computer ability self-efficacy on students learning outcomes. This type of research was a qualitative research with experimental design in nonequivalent control group design. Where this research consists of a control class and an experimental class which was applied to class VIII at SMP Negeri 6 Makassar and SMP Negeri 19 Makassar. Before conducting the research, a trial was conducted to determine the needs of students. This study used two variables, namely computer-based test (CBT) and selfefficacy of computer ability and the dependent variable on learning outcomes in mathematics at SMP Negeri in 
Makassar City.This study was conducted to see the impact of computer-based test (CBT) and self-efficacy of computer skills on student learning outcomes in class VIII mathematics at SMP Negeri 6 Makassar and SMP Negeri 19 Makassar. Computer-based test (CBT) was a web-based evaluation tool that can be done on a computer or mobile phone. Therefore, the implementation of the evaluation using computer-based test (CBT) can be implemented on all students. In accordance with the opinions of students. The computer-based test (CBT) application was very helpful for teachers and students in evaluating learning in the Covid Pandemic 19 era. Therefore this research had a very positive response to the school.

The research was conducted at SMP Negeri 6 Makassar with this type of experimental research consisting of a sample of 32 students who were divided into 2 groups, namely the experimental group as many as 16 students and the control group as many as 16 students. The analysis was obtained based on the results of initial observations on students and interviews with teachers. Information obtained after preliminary observations, namely how to improve student learning outcomes by using computer-based tests (CBT) on students so that students practice using computer-based tests (CBT) more often in evaluating learning outcomes. This research was conducted during the Covid 19 pandemic by implementing distance learning at home and the evaluation tool used was a computer-based test (CBT) to see student learning outcomes whether the learning outcomes had met the KKM standard or not. Based on the results of experiments conducted at SMP Negeri 6 Makassar, it can be seen that the value of mathematics learning outcomes has met the KKM standard, which is an average of 85.5. While at SMP Negeri 19 Makassar the research was applied with a sample of 32 students consisting of 16 experimental students and 17 students who were in the control group.

\section{Discussion}

There are some previous studies stated that the student self-efficacy had a major influence on students' mathematical thinking in solving mathematical problems (Gazali, 2017; Liao et al., 2018). This is because mathematics holds a prominent place in the academic curriculum, and academic success in this subject is very important in today's fast-paced scientific and technological age, so self-efficacy is very important in solving mathematical problems (Imam et al., 2018; Nurdin et al., 2019; Santosa et al., 2020). This study conveyed that ICT self-efficacy is positively related to computer and information literacy when controlled for other student characteristics and background contextual variables and ICT self-efficacy one hand and computer and information literacy on the other. It is therefore necessary to continue elaborating on the differences between what students belief they can do when using ICT and their actual performance with ICT (Hatlevik et al., 2018a; Malik, 2018). Also this study was supported that self-efficacy varied depending on the number of scientific congresses attended within the year, number of papers written, subscriptions to scientific journals, and daily length of computer use for scientific purposes (Liao et al., 2018; Yaldiz \& Bailey, 2019). These results showed that computer self-efficacy and subjective well-being are significant predictors of belief in

The interaction between variables can be seen by the correlation results based on the research conducted, it was obtained that the computer-based test had a very perfect interaction with a value of 0.81 and it was positive. Therefore, if students had high self-efficacy, the higher the learning outcomes obtained by using a computer-based test (CBT). The results of a significant relationship between self-efficacy and mathematics performance (Taştan et al., 2018; Ulinnuha et al., 2021). The test using a computer-based test (CBT) really helps students and teachers in conducting evaluations that are carried out in each student's home (Balogun \& Olanrewaju, 2016; Wardani \& Setyadi, 2020). Self efficacy computer skills are very influential on students' mathematics learning outcomes. Because the level of self-confidence of each student in doing tests using a computer is very confident. The higher the self-efficacy of students' computer skills, the higher the value of learning outcomes obtained using the Computer-based test (CBT) in mathematics. Self efficacy and computerbased test (CBT) on learning outcomes have a very high interaction or are called to be perfect interaction. The obstacles in conducting this research is not doing face-to-face but online. This makes researchers have limitations in terms of seeing directly the experimental research carried out. And the provision of computers is limited to students who do not have. Therefore, researchers provide an alternative that computer-based tests can be accessed on cellphones even though they are limited.

\section{CONCLUSION}

Student learning outcomes in mathematics subjects in the group of students who are provided computerbased test treatment and the group of students who used the paper test showed different results. Student learning outcomes in mathematics subjects in the experimental group and the control group showed different results of self-efficacy in computer skills. Therefore, there is an effect of self-efficacy of computer abilities on student learning outcomes in mathematics. Computer self-efficacy positively influences learning outcomes. Computer self-efficacy reveals mediating effects between learning outcomes and Computer self-efficacy. 


\section{REFERENCES}

Abosalem, Y. (2016). Assessment techniques and students' higher-order thinking skills. International Journal of Secondary Education, 4(1), 1-11. https://doi.org/10.11648/j.ijsedu.20160401.11.

Achim, N., \& Kassim, A. Al. (2015). Computer Usage: The Impact of Computer Anxiety and Computer Selfefficacy. Procedia - Social and Behavioral Sciences, 172, 701-708. https://doi.org/10.1016/j.sbspro.2015.01.422.

Azizah, U., Djono, D., \& Musadad, A. A. (2020). Developing Digital Book Based on Lafran Pane’ Thought for Increasing State Defend Attitude of Students. Yupa: Historical Studies Journal, 4(1), $29-39$. https://doi.org/10.30872/yupa.v4i1.235

Balogun, A. G., \& Olanrewaju, A. S. (2016). Role of Computer Self-Efficacy and Gender in Computer-Based Test Anxiety Among Undergraduates in Nigeria. Psychological Thought, 9(1). https://doi.org/10.5964/psyct.v9i1.160.

Barnes, S. J., Pressey, A. D., \& Scornavacca, E. (2019). Mobile ubiquity: Understanding the relationship between cognitive absorption, smartphone addiction and social network services. In Computers in Human Behavior (Vol. 90). Elsevier B.V. https://doi.org/10.1016/j.chb.2018.09.013.

Bressington, D. T., Wong, W. kit, Lam, K. K. C., \& Chien, W. T. (2018). Concept mapping to promote meaningful learning, help relate theory to practice and improve learning self-efficacy in Asian mental health nursing students: A mixed-methods pilot study. Nurse Education Today, 60(February 2017), 4755. https://doi.org/10.1016/j.nedt.2017.09.019.

Chua, Y. P., \& Don, Z. M. (2013). Effects of computer-based educational achievement test on test performance and test takers' motivation. Computers in Human Behavior, 29(5). https://doi.org/10.1016/j.chb.2013.03.008.

Daniels, L. M., \& Gierl, M. J. (2017). The impact of immediate test score reporting on university students' achievement emotions in the context of computer-based multiple-choice exams. Learning and Instruction, 5(2). https://doi.org/10.1016/j.learninstruc.2017.04.001.

Dashtestani, R. (2013). Implementing mobile-assisted language learning (MALL) in an EFL context: Iranian EFL teachers' perspectives on challenges and affordances. The JALT CALL Journal, 9(2), 149-168. https://doi.org/10.29140/jaltcall.v9n2.153.

Dong, Y., Xu, C., Chai, C. S., \& Zhai, X. (2020). Exploring the Structural Relationship Among Teachers' Technostress, Technological Pedagogical Content Knowledge (TPACK), Computer Self-efficacy and School Support. Asia-Pacific Education Researcher, 29(2), 147-157. https://doi.org/10.1007/s40299019-00461-5.

Fonda, A., \& Sumargiyani, S. (2018). The Developing Math Electronic Module With Scientific Approach Using Kvisoft Flipbook Maker Pro For Xi Grade Of Senior High School Students. Infinity Journal, 7(2), 109122. https://doi.org/10.22460/infinity.v7i2.p109-122.

Gazali, M. (2017). Pengaruh Efikasi Diri dan Kecemasan Matematika terhadap Kemampuan Berpikir Kritis. Jurnal Penelitian Pendidikan Dan Penilaian Pendidikan, 2(2), 274-289. https://doi.org/10.22236/JPPP.

Hatlevik, O. E., Throndsen, I., Loi, M., \& Gudmundsdottir, G. B. (2018a). Students' ICT self-efficacy and computer and information literacy: Determinants and relationships. Computers and Education, 118, 107-119. https://doi.org/10.1016/j.compedu.2017.11.011

Hatlevik, O. E., Throndsen, I., Loi, M., \& Gudmundsdottir, G. B. (2018b). Students' ICT self-efficacy and computer and information literacy: Determinants and relationships. Computers and Education, 118(November 2017), 107-119. https://doi.org/10.1016/j.compedu.2017.11.011.

Hung, C.-M., Huang, I., \& Hwang, G.-J. (2014). Effects of digital game-based learning on students' selfefficacy, motivation, anxiety, and achievements in learning mathematics. Journal of Computers in Education, 1(2-3), 151-166. https://doi.org/10.1007/s40692-014-0008-8.

Hussein, E., Daoud, S., Alrabaiah, H., \& Badawi, R. (2020). Exploring undergraduate students' attitudes towards emergency online learning during COVID-19: A case from the UAE. Children and Youth Services Review, 119(10), 105699. https://doi.org/10.1016/j.childyouth.2020.105699.

Hwang, I. H., Chang, C. C., Wang, H. L., Tsai, S. J., \& Chen, T. Y. (2011). Mediating effects of computer selfefficacy between learning motivation and learning achievement. Advances in Intelligent and Soft Computing, 109, 67-73. https://doi.org/10.1007/978-3-642-24772-9_10.

Imam, I., Ayubi, A., \& Bernard, M. (2018). Pengaruh Pembelajaran Berbasis Masalah Terhadap Kemampuan Pemecahan Masalah Matematis Siswa SMA. JPMI:Jurnal Pembelajaran Matematika Inovatif, 1(3), 355-360. https://doi.org/10.22460/jpmi.v1i3.355-360.

Inceday1, N. (2018). The Impact of Using Multimedia Technologies on Students Academic Achievement in the Bakirköy Final College. International Journal of Humanities, Social Sciences and Education, 5(1), 4047. https://doi.org/10.20431/2349-0381.0501007. 
Kartika, Y., Wahyuni, R., Sinaga, B., \& Rajagukguk, J. (2019). Improving Math Creative Thinking Ability by using Math Adventure Educational Game as an Interactive Media. Journal of Physics: Conference Series, 1179(1), 1-6. https://doi.org/10.1088/1742-6596/1179/1/012078.

Liao, S., Hong, J.-C., Wen, M.-H., Pan, Y.-C., \& Wu, Y.-. (2018). Applying Technology Acceptance Model (TAM) to explore Users' Behavioral Intention to Adopt a Performance Assessment System for E-book Production. EURASIA Journal of Mathematics, Science and Technology Education, 14(10). https://doi.org/10.29333/ejmste/93575.

Malik, R. S. (2018). Educational Challenges in 21st Century and Sutainable Development. Journal of Sustainable Development Education and Research, 2(1), 9-20. https://doi.org/10.17509/jsder.v2i1.12266.

Mpungose, C. B. (2021). Lecturers' reflections on use of Zoom video conferencing technology for e-learning at a South African university in the context of coronavirus. African Identities. https://doi.org/10.1080/14725843.2021.1902268.

Nurdin, E., Ma'aruf, A., Amir, Z., Risnawati, R., Noviarni, N., \& Azmi, M. P. (2019). Pemanfaatan video pembelajaran berbasis Geogebra untuk meningkatkan kemampuan pemahaman konsep matematis siswa SMK. Jurnal Riset Pendidikan Matematika, 6(1), 87-98. https://doi.org/10.21831/jrpm.v6i1.18421.

Odaci, H. (2013). The Role of Computer Self-efficacy, Self-esteem, and Subjective Well-being in Predicting Research Self-efficacy Among Postgraduate Students. Asia-Pacific Education Researcher, 22(4), 399406. https://doi.org/10.1007/s40299-012-0039-8.

Pellas, N. (2014). The influence of computer self-efficacy, metacognitive self-regulation and self-esteem on student engagement in online learning programs: Evidence from the virtual world of Second Life. Computers in Human Behavior, 35, 157-170. https://doi.org/10.1016/j.chb.2014.02.048.

R. Burke Johnson, L. C. (2014). Educational Research Quantitative, Qualitative, and Mixed Approaches. In SAGE Publications India Pvt. Ltd (5th ed., Vol. 4, Issue 1). Library of Congress Cataloging-inPublication Data. https://doi.org/10.4324/9781351004626-12.

Rachmawati, T. K. (2018). Pengaruh Metode Ekspositori Pada Pembelajaran Matematika Dasar Mahasiswa Manajemen Pendidikan Islam. Jurnal Pendidikan Edutama, 5(1). https://doi.org/10.30734/jpe.v5i1.130.

Rosidah, Ketut Budayasa, I., \& Juniati, D. (2018). An Analysis of Statistical Reasoning Process of High School Students in Solving the Statistical Problem. Journal of Physics: Conference Series, 1028(1). https://doi.org/10.1088/1742-6596/1028/1/012125.

Safi'i, A., \& Bharata, H. (2021). Hubungan Kemampuan Pemecahan Masalah dan Pemahaman Konsep Matematis terhadap Kemampuan Computer Self-Efficacy. JKPM (Jurnal Kajian Pendidikan Matematika), 6(2), 215. https://doi.org/10.30998/jkpm.v6i2.9826.

Sagala, P. N., \& Andriani, A. (2019). Development of Higher-Order Thinking Skills (HOTS) Questions of Probability Theory Subject Based on Bloom's Taxonomy. Journal of Physics: Conference Series, 1188(1). https://doi.org/10.1088/1742-6596/1188/1/012025.

Santosa, F. H., Negara, H. R. P., \& Samsul Bahri. (2020). Efektivitas Pembelajaran Google Classroom Terhadap Kemampuan Penalaran Matematis Siswa. Jurnal Pemikiran Dan Penelitian Pendidikan Matematika (JP3M), 3(1), 62-70. https://doi.org/10.36765/jp3m.v3i1.254.

Sun, J. C. Y., \& Rueda, R. (2012). Situational interest, computer self-efficacy and self-regulation: Their impact on student engagement in distance education. British Journal of Educational Technology, 43(2), 191204. https://doi.org/10.1111/j.1467-8535.2010.01157.x.

Taruh, E., Abbas, N., \& Umar, M. K. (2019). Studies The Influence Of Blended Learning-Based Guided Inquiry Learning Model And Self Efficacy On Students' Scientific Literacy. European Journal Of Education, 1, 137-150. https://doi.org/10.5281/zenodo.3445474.

Taştan, S. B., Davoudi, S. M. M., Masalimova, A. R., Bersanov, A. S., Kurbanov, R. A., Boiarchuk, A. V., \& Pavlushin, A. A. (2018). The impacts of teacher's efficacy and motivation on student's academic achievement in science education among secondary and high school students. Eurasia Journal of Mathematics, Science and Technology Education, 14(6), 2353-2366. https://doi.org/10.29333/ejmste/89579.

Tse, W. S., Choi, L. Y. A., \& Tang, W. S. (2019). Effects of video-based flipped class instruction on subject reading motivation. British Journal of Educational Technology, 50(1), 385-398. https://doi.org/10.1111/bjet.12569.

Ulinnuha, R., Budi Waluya, S., \& Rochmad, R. (2021). Creative Thinking Ability With Open-Ended Problems Based on Self-Efficacy in Gnomio Blended Learning. Unnes Journal of Mathematics Education Research, 10(A), 20-25. https://journal.unnes.ac.id/sju/index.php/ujmer/article/view/34277.

Valle, S. C., Støen, R., Sæther, R., \& Sæther, R. (2019). Test-retest reliability of computer-based video analysis of general movements in healthy term-born infants. Early Human Development, 91(10). https://doi.org/10.1016/j.earlhumdev.2015.07.001. 
Wardani, K. W., \& Setyadi, D. (2020). Pengembangan Media Pembelajaran Matematika Berbasis Macromedia Flash Materi Luas dan Keliling untuk Meningkatkan Motivasi Belajar Siswa. Scholaria: Jurnal Pendidikan Dan Kebudayaan, 10(1), 73-84. https://doi.org/10.24246/j.js.2020.v10.i1.p73-84.

Yada, A., Björn, P. M., Savolainen, P., Kyttälä, M., \& Aro, M. (2021). Pre-service teachers' self-efficacy in implementing inclusive practices and resilience in Finland. Teaching and Teacher Education, 105. https://doi.org/10.1016/j.tate.2021.103398.

Yaldiz, N., \& Bailey, M. (2019). The Effect of Critical Thinking on Making the Right Decisions in the New Venture Process. Procedia Computer Science, 158, 281-286. https://doi.org/10.1016/j.procs.2019.09.053.

Yuzulia, I. (2021). The Challenges of Online Learning during Pandemic: Students' Voice. Wanastra: Jurnal Bahasa Dan Sastra, 13(1), 08-12. https://doi.org/10.31294/w.v13i1.9759.

Zetriuslita, Nofriyandi, \& Istikomah, E. (2020). The Increasing Self-Efficacy and Self-Regulated through GeoGebra Based Teaching reviewed from Initial Mathematical Ability (IMA) Level. International Journal of Instruction, 14(1), 587-598. https://doi.org/10.29333/IJI.2021.14135A.

Zijlstra, H., van Bergen, E., Regtvoort, A., de Jong, P. F., \& van der Leij, A. (2021). Prevention of reading difficulties in children with and without familial risk: Short- and long-term effects of an early intervention. Journal of Educational Psychology, 113(2). https://doi.org/10.1037/edu0000489. 